\title{
Post-fire flowering and fruiting in Vellozia sincorana, a caulescent rosette plant endemic to Northeast Brazil
}

\author{
Abel Augusto Conceição ${ }^{1,3}$ and Barron J. Orr ${ }^{2}$
}

Recebido em 14/06/2011. Aceito em 10/01/2012

\begin{abstract}
RESUMO
(Floração e frutificação depois de fogo em Vellozia sincorana, planta caulescente de roseta endêmica do Nordeste do Brasil). Vellozia sincorana L.B. Sm. \& Ayensu é uma espécie endêmica dos campos rupestres ameaçada pela coleta de seus ramos resinosos destinados a acender fogões. A floração em massa de $V$. sincorana observada depois de incêndio em outubro de 1999 suscitou as seguintes perguntas: $O$ fogo afeta a floração e frutificação de $V$. sincorana? A altura dos indivíduos é correlacionada com a produção de flores e frutos? Um incêndio em 08 de novembro de 2008 foi oportuno para explorar essas questões. Foram monitoradas populações de V. sincorana em duas áreas de

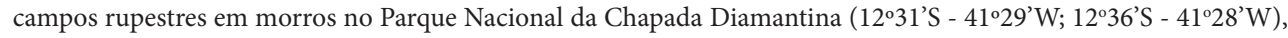
uma acometida pelo incêndio de novembro de 2008 e a outra não queimada desde 1999. Em ambas as áreas, 25 indivíduos foram sorteados e monitorados. Os números de flores e frutos foram contados e as alturas das plantas foram medidas em nove amostragens realizadas entre 2008 e 2010. Correlação de Spearman e regressão linear foram utilizadas para avaliar a relação entre altura dos indivíduos e a fenologia. Floração e frutificação ocorreram apenas na população queimada a menos tempo, cerca de 40 dias depois do fogo e em 24 dos 25 indivíduos monitorados (96\%). A quantidade de flores e/ou frutos foi positivamente e significativamente correlacionada com a altura das plantas. A abundante floração depois do incêndio é um indicativo do fogo como fator que dispara essa fase fenológica. Estimativa da idade de indivíduos altos e eventos de floração podem ser utilizados para estimar a frequência do fogo em áreas de populações de V. sincorana, contribuindo para o conhecimento da ecologia do fogo e para conservação biológica e manejo do fogo nos campos rupestres.
\end{abstract}

Palavras-chave: campos rupestres, Chapada Diamantina, fenologia, planta útil, Velloziaceae

\begin{abstract}
(Post-fire flowering and fruiting in Vellozia sincorana, a caulescent rosette plant endemic to Northeast Brazil). Vellozia sincorana L.B. Sm. \& Ayensu, an endemic of campos rupestres, is an endangered species collected by local people to start cooking fires due to the flammability of its resinous stems. A massive flowering of $V$. sincorana following a wildfire in October 1999 raised some questions: Does fire affect flowering and fruiting of V. sincorana? Is the height of individuals correlated with flowering and fruit production? A wildfire event on 8 November 2008 provided an opportunity to explore these questions. Two populations of V. sincorana in two campos rupestres sites (12³1'S - 41 $29^{\prime} \mathrm{W}$; $12^{\circ} 36^{\prime} \mathrm{S}-41^{\circ} 28^{\prime} \mathrm{W}$ ) on ridgetops in the Chapada Diamantina National Park (Brazil) were monitored, one burned in the November 2008 fire and the other unburned since the 1999 fire. In both sites, 25 individuals were randomly labeled and monitored. Nine plant samplings were conducted between 2008 and 2010, during which the number of flowers and fruits were tallied and the heights measured. Spearman's rank correlation coefficient and linear regression were used to evaluate the relationship between the height of individuals and phenology. Flowering and fruiting occurred only in the recently burnt population, about 40 days after the fire, in 24 of the 25 individuals monitored (96\%). The quantity of flower and/or fruit was positively and significantly correlated with plant height. The abundant flowering after fire suggests that fire triggers this phenological phase. Estimates of age of the taller individuals and the periods of flowering can be used to estimate fire frequency in the V. sincorana population sites, which contributes to the knowledge of fire ecology and is useful for conservation biology and fire management of campos rupestres.
\end{abstract}

Key words: Chapada Diamantina, phenology, rupestrian fields, useful plant, Velloziaceae

\footnotetext{
1 Universidade Estadual de Feira de Santana, Departamento de Ciências Biológicas, Laboratório Flora e Vegetação, Feira de Santana, BA, Brasil

2 University of Arizona, School of Natural Resources and the Environment, Office of Arid Lands Studies, Tucson, AZ, USA

3 Author for correspondence: abel18@gmail.com
} 


\section{Introduction}

Vellozia sincorana (Velloziaceae), or candombá, is a species endemic to campos rupestres of the Chapada Diamantina (Bahia State, NE Brazil) (Smith \& Ayensu 1976), and is collected by local people to start cooking fires because of its resinous stems (Alves 1994; Funch et al. 2004). Other species of the same habit have been described as resistant to fire, with the capacity to resprout their leaf rosette after burning, and flower considerably following a fire (Lamont \& Downes 1979; Givnish et al. 1986; Curtis 1998; Taylor et al. 1998; Mello-Silva 2004), with taller individuals flowering more than shorter ones (Curtis 1998; Lamont et al. 2000).

Several papers report the importance of fire in the sexual reproduction of plant species in different ecosystems (Coutinho 1977; Lamont \& Downes 1979; Pyke 1983; Givnish et al. 1986; Johnson et al. 1994; Taylor et al. 1998; Lamont et al. 2000; Verboom et al. 2002; Bowen \& Pate 2004; Franceschinelli \& Bawa 2005; Schmidt et al. 2005; Paula \& Pausas 2008). However, fire is also viewed as an undesirable disturbance with negative impacts on the local, regional and even global environment, influencing climatic patterns, and sometimes precipitating changes in vegetation communities, mitigated by ecosystem type, local site characteristics, the season of year, frequency of fire, and the amount of dry combustible material accumulated, among other factors (McNeely et al. 1990; Whelan 1995; RamosNeto \& Pivello 2000; Franceschinelli \& Bawa 2005; Pivello 2006; Cochrane 2009).

Fire can destroy the flowers and fruits of a plant, or promote opening of the fruits in serotinous species (Coutinho 1977; Whelan 1995), highlighting the importance of the plant phenophase with the fire. In Brazilian savanna, fires early in the season kill most of seeds of Heteropterys pteropetala A. Juss. because they are still attached to the motherplants, while in mid- and end-fires seeds have already been released and may be buried and protected from extreme temperatures during the burning (Schmidt et al. 2005). However, the buried seeds are not an assurance of plant recruitment, at least for Vellozia alata L.B. Sm., because the potential for germination of its seeds decreases in few months (Munné-Bosch et al. 2011). Velloziaceae is an important family for conservation biology (Munné-Bosch et al. 2011), with 211 species from Brazil, of which 208 are endemic to this country (Mello-Silva 2010). Vellozia sincorana is a threatened species, is endemic to campos rupestres in Bahia, and its populations are under pressure from human activities (Funch et al. 2004).

The botanical description of $V$. sincorana was made in 1976 based on single voucher from the Chapada Diamantina (Smith \& Ayensu 1976). This scarcity of botanical material may be related to the limited geographic distribution of this species, or more likely to the flowering time, if this is restricted to burning episodes. Additionally, other species from the same genus have massive yet very brief blooming phases that offer a lot of resources to a diversity of insects (Mello-Silva 2004; Jacobi \& Sarto 2007).

This study aims to answer two main questions. Does fire affect the flowering and fruiting of $V$. sincorana? Is the height of individuals correlated with flowering and fruit production?

\section{Material and methods}

This study was carried out in two sites of campos rupestres (rocky savannas or rupestrian fields) in the Serra do Sincorá (Sincorá Range), in the municipality of Palmeiras, Chapada Diamantina National Park, in the state of Bahia, in northeastern Brazil, which has elevations between 1040 to $1200 \mathrm{~m}$ a.s.l. (Fig. 1). Sandstone and quartzites formed in the Pre-Cambrian, characterized by markedly differential erosion rates, make up the rugged topography of the Chapada Diamantina (Moreira \& Camelier 1977).

The climate at the study sites is mesothermic, with a humid summer and four to five dry months concentrated during the winter. From June to August (winter), conditions are cooler and the early morning hours are often cloudy. Mean annual temperatures at locations with elevations between 1000 and $1100 \mathrm{~m}$ are lower than $20^{\circ} \mathrm{C}$, and minimum daily temperatures lower than $4^{\circ} \mathrm{C}$ may occur (Nimer 1989). The rainfall measured by the "Orquidário do Pai Inácio" Weather Station (12 $27^{\prime} \mathrm{S}-41^{\circ} 27^{\prime} \mathrm{W}, 885 \mathrm{~m}$ a.s.l.) (Fig. 2), which is 6 and $9 \mathrm{~km}$ from the study sites, shows the regional precipitation highlighting the wet (December to April) and dry (June to October) seasons, as well as anomalously high rainfall in October 2009.

Campos rupestres physiognomies are a mix of herbaceous and shrubby plant communities, including grassdominated ones. These occur predominantly on sandy soils, islands of vegetation on rock outcrops, and in the shrubbygrassy continuous vegetation boundary found among rock outcrops (Conceição \& Pirani 2005; Conceição et al. 2007b; Neves \& Conceição 2010).

The two campos rupestres sites in the Serra do Sincorá were selected because of: a) relatively high concentration of the target species; b) proximity between them; and c) similarities in habitat, including key biophysical characteristics (elevation, slope, aspect, soils, climate, and vegetation structure) with the exception of fire history. The recently burned site is located at Morro dos Ventos (12 ${ }^{\circ} 31^{\prime} S ; 41^{\circ}$ $\left.29^{\prime} \mathrm{W}\right)$; the wildfire occurred 15 days prior to data collection, on 8 November 2008 (Fig. 1). The second site is located

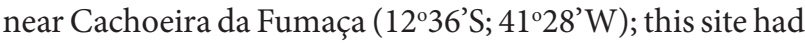
a wildfire ten years prior to the data collection period. The distance between the sites is $7 \mathrm{~km}$.

In both sites, 25 individual plants of $V$. sincorana (n $=50$ ) were randomly selected and labeled for repeated observations timed to capture the rapid post-fire onset of flowering and subsequent fruiting, as reported in other species of this family (Jacobi \& Sarto 2007). Three visits in 
2008 (23 November; 7 and 30 December), five in 2009 (25 January, 24 February, 7 March, 3 May, 6 November) and one in 2010 (25 January) were carried out. Measurements included numbers of flowers and fruits per individual and per branch. Individuals of this species usually have more than one aerial branch, including the old leaf-bases from rosettes (Smith \& Ayensu 1976). The fruit is a capsule and the presence of seedy and seedless capsules per individual was identified in the field. The longest and shortest branches of each individual were measured.

Spearman's rank correlation coefficients, and linear regression, were used to evaluate the relationship between an individual's maximum height (based on the longest branch) and minimum height (based on shortest branch) and the range of height determined by difference of height of the longest and shortest branches (independent variables) and two dependent variables: the number of flowers and/ or fruits and fertile branches (the number of branches in flowering and/or fruiting). The Kolmorogov-Smirnov test was used to confirm the assumption of normality $(p<0,05)$. Calculations were performed with Systat (version 12.02.00 Systat Inc, San Jose, CA, US).

\section{Results}

The 25 adult individuals of $V$. sincorana burnt in Morro dos Ventos on 8 November 2008 survived, and their rosette leaves resprouted rapidly, on the extremes of aerial branches, 15 days after fire (Fig. 1). Flowering and/or fruiting occurred on 24 of the 25 individuals (96\%) within approximately 40 days of the 8 November 2008 wildfire (Fig. 3). By contrast, no flowering or fruiting occurred in the population near Cachoeira da Fumaça, which had not experienced a wildfire in ten years.

Observations on 7 December 2008 (no flowers) and 30 December 2008 (50 flowers and 511 fruits) revealed that the plants produced a minimum 511 flowers between 8 and 29 December; no direct observations were made between sampling periods (Fig. 4). Observations of flower and fruit visitation and predation by insects suggest that the overall resources available to animals are potentially higher. In 25 January 2009 (79 days after the fire), 530 fruits and no flowers were observed. These observations highlight the short flowering period observed (approximately 30 days) for this species (Fig. 4). From 200 branches with leaves (8.0 \pm 3.74), $77.5 \%$ had flowers and fruits on 30 December 2008 (53 days after the fire) and $72 \%$ had them on 25 January 2009 (79 days after the fire). All individuals that flowered had fruits, with 1 to 7 flowers/fruits per branch. On 30 December 2008 there were 511 seedy capsules. On 24 February 2009 there were 509 capsules, 45 capsules contained seeds. On 3 May 2009 there were 505 capsules attached to the 24 individuals, but none contained seeds. After one year of fruit production, there were 490 seedless capsules (97\%) attached to the branches (Fig. 3 and 4).
The total number of flowers and/or fruits and the number of fertile branches were positively and significantly correlated with the range of height and the maximum height of individuals (Tab. 1). The regression between plant height and the presence of flowers and/or fruits on individuals was not performed because of the high ratio of flowering and fruiting (24/25). The normal distribution was confirmed and the regressions were significant in maximum height and range of height (Fig. 5). The distribution of minimum height regression was not normal. The single individual that did not flower was the one with the shortest branches in the sample set (ranging from 40 to $50 \mathrm{~cm}$ ). The two tallest individuals had branches between 60 and $100 \mathrm{~cm}$ height. The mean branch height among all 25 individuals was 77.3 $\mathrm{cm}(\mathrm{SD}=14)$. The mean number of fertile branches per individual was $6.2(\mathrm{SD}=3.6)$.

\section{Discussion}

The clear difference in flowering and fruiting between the recently burned site and the site observed 10 years after a fire suggest that fire is a key factor for $V$. sincorana flowering and reproduction. While fire appears to be the dominant control on the timing of flowering, other factors such as temperature, photoperiod and precipitation should also be investigated for their contribution to regulating the timing of flowering after a fire. In other Velloziaceae species, flowering is correlated with climatic factors (Conceição et al. 2007a), and may have a supplementary influence on phenological timing in this case. During this study period, the rainfall accumulated between fire occurrence and the major flowering event (45 days) was high (206 mm). In Xanthorrhoea fulva (A.Lee) Bedford, a plant with a stem rosette from Australia, there was a seasonal effect of fire on the timing of flowering; however, the time to inflorescence production was similar for the summer and spring fires, which was about six months (Taylor et al. 1998). Fire interval is another important feature because the percentage of plants in flower declines as the time since the last burn increases (Pyke 1983; Taylor et al. 1998).

The specialized root and rosette system of $V$. sincorana may help this species maximize the use of available moisture in order to have a massive flowering phase soon after a fire. Adventitious roots sprout from the living portion of the stem, growing downward through the dead dry leaf matter that forms the caudex (Fig. 1B; Smith \& Ayensu 1976; Alves 1994). These are able to gather moisture from fog and rain and at the same time protect the stem from fires (Kubitzki 1998). Vellozia species have a velamen radicum that has been reported to aid in absorbing atmospheric moisture and is important for water uptake (Porembski \& Barthlott 1995). The stem rosette is a typical monocotyledonous lifeform from mountains that periodically burn (Lamont \& Downes 1979; Givnish et al. 1986; Ramsay \& Oxley 1996; Curtis 1998; Taylor et al. 1998; Safford 2001; Kolbek \& Alves 

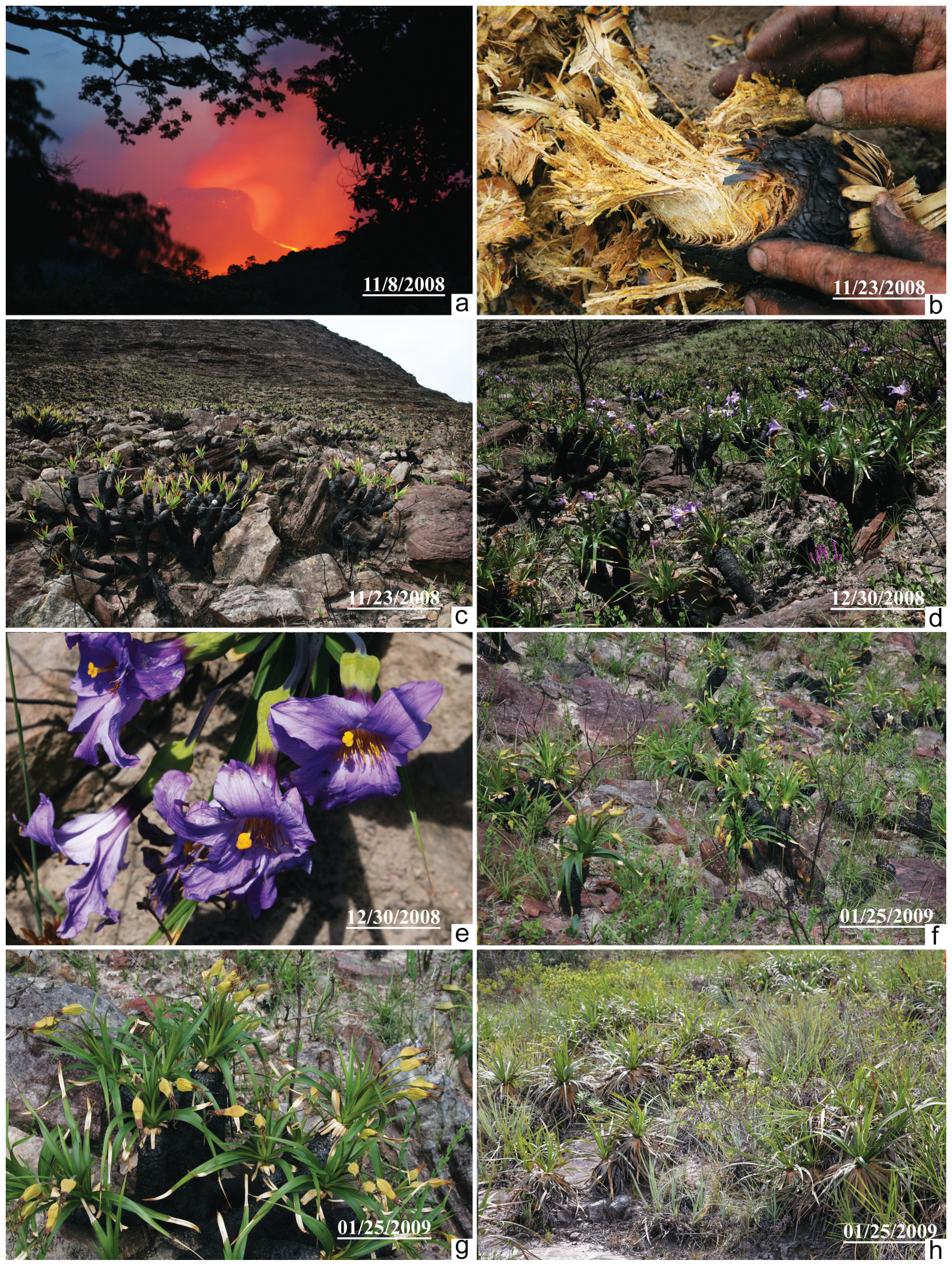

Figure 1. Vellozia sincorana in Chapada Diamantina National Park, Bahia, Brazil. (A-G) Burned population in Morro dos Ventos (12 $\left.31^{\prime} \mathrm{S}-41^{\circ} 29^{\prime} \mathrm{W}\right)$ at $1040 \mathrm{~m}$ a.s.l. (A) Fire occurred on 8 November 2008. (B) Branches used to start cooking fires. (C-G) Time sequence of aerial branch resprouts, flowering and fruiting. (H) Control population near Cachoeira da Fumaça $\left(12^{\circ} 36^{\prime} \mathrm{S}-41^{\circ} 28^{\prime} \mathrm{W}\right)$ at $1200 \mathrm{~m}$ a.s.l. 


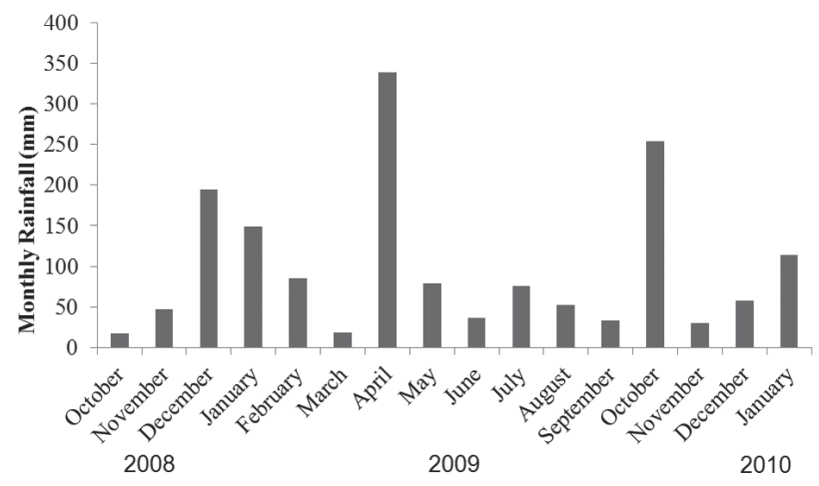

Figure 2. Monthly rainfall from October 2008 to February 2010 in Chapada Diamantina, Bahia, Brazil. Source: Orquidário do Pai Inácio Weather Station (12 $27^{\prime} \mathrm{S}-41^{\circ} 27^{\prime} \mathrm{W}, 885 \mathrm{~m}$ a.s.l.).

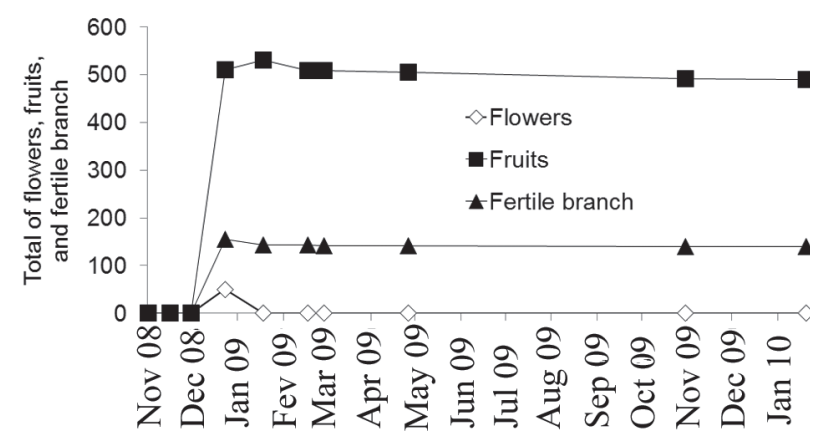

Figure 4. Total flowers, fruits, and fertile branches from 25 individuals of Vellozia sincorana that were burned in Morro dos Ventos, Chapada Diamantina National Park, Bahia, Brazil. The symbols correspond to the nine sequential observations after the 08 November 2008 fire.

2008). However, other species in the Velloziaceae that are endemic to the rocky savanna of the Chapada Diamantina, such as Vellozia punctulata Seub., are sensitive to fire (Neves \& Conceição 2010).

Post-fire flowering of Vellozia sincorana contributes to how the ecosystem functions in the campos rupestres where they grow. The abundant flowering and fruiting in the weeks immediately following a fire creates a sudden, abundant supply of resources for local fauna. This, in turn, can have a positive system-wide effect on pollination and fruit production (Franceschinelli \& Bawa 2005). Seed dispersal during the wet season and the pulse of nutrients after burning (Johnson et al. 1994; Whelan 1995) may benefit the germination and establishment of plants following fires that occur at the end of the dry season, which happened in this study of $V$. sincorana. The seeds of $V$. sincorana were released $c a$. six months before the dry season, which corresponded to a period of decreasing potential for the germination of V. alata (Munné-Bosch et al. 2011).

During this study no seed germination or plant establishment were observed, despite the high number of seeds on the ground near the mother-plants. This fact may be due to the high amount of rain in April 2009 (Fig. 2) that could have carried away the seeds; other Vellozia species

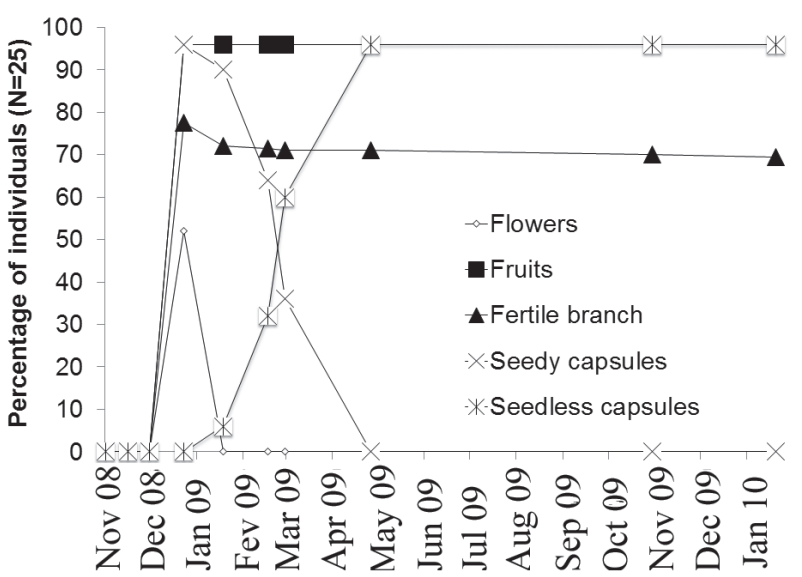

Figure 3. Percentage of 25 individuals of Vellozia sincorana with flowers and fruits, and the percentage of fertile branches among 200 branches assessed that resprouted at the burned site in Morro dos Ventos, Chapada Diamantina National Park, Bahia, Brazil. The symbols correspond to the nine sequential observations after the 8 November 2008 fire.

from campos rupestres germinate under a wide range of temperature and light and are compatible with this kind of ecosystem (Garcia \& Diniz 2003). Regardless of wildfire, the community has a high proportion of $V$. sincorana (Fig. 1), and possibly root competition and shading by $V$. sincorana individuals has a negative effect on establishment, as with sprouts of Erica multiflora L. (Montserrat 1997).

The occurrence of more flowers and/or fruits on taller individuals may be correlated with fire and fire temperature, since the most combustible part of this kind of vegetation is physically near the ground (Conceição \& Pirani 2005; Midgley et al. 2010), where higher temperatures probably occur. As such, the reproductive plant parts of taller individuals can escape from higher temperatures. Taller (and therefore larger) individuals suggest a greater capacity for concentration of nutrient and water reserves, and greater visibility of the flowers to pollinators. Higher flowering of taller individuals may also be explained by correspondingly greater branch volume, which provides more area for flowering.

It is useful to know whether fire is an essential condition to flowering, as this research suggests for $V$. sincorana. Other species that flower after a fire may also flower sporadically, as with an Australian monocotyledon (Blandfordia nobilis Sm.) (Johnson et al. 1994), two species with stem rosettes [Xanthorrhoea australis R.Br. (Curtis 1998) and X. fulva (Taylor et al. 1998)], and a eudicotyledonous undershrub (Stirlingia latifolia R.Br., Bowen \& Pate 2004). A monocotyledon endemic of the fynbos in South Africa (Ehrharta capensis Thunb) was shown to flower after pruning its leafs and providing it with nutrients, supporting the idea of that shoot destruction and changes in soil attributes are features related to high flowering after a fire in some species (Verboom et al. 2002). In Australia, the burning and clipping of tufted leaves stimulated inflorescence production of $X$. fulva (Taylor et al. 1998). 
Table 1. Spearman ranks correlation $\left(\mathrm{r}_{\mathrm{s}}\right.$ ) between plant height variables and total number of flowers and fruits and total number of branches with flowers and fruits, for 25 individuals of Vellozia sincorana (Velloziaceae) that were sampled on 30 December 2008 in the Serra do Sincorá, Bahia, Brazil.

\begin{tabular}{lccc}
\hline & Maximum height & Minimum height & Amplitude of height \\
\hline Total number of flowers and/or fruits & $0.541^{*}$ & -0.234 & $0.711^{*}$ \\
Total number of branches in flowering and/or fruiting & $0.631^{*}$ & -0.211 & $0.741^{*}$ \\
\hline
\end{tabular}

${ }^{*}$ Significant correlation $(P<0.05)$.

During more than ten years of study in the campos rupestres of the Chapada Diamantina, we observed V. sincorana flowering events on only two occasions, both following wildfires, including the one in this study (2008) and another following a large fire in a population in Cachoeira da Fumaça (1999). After the 1999 fire, like in 2008, flowering was observed only in individuals located in burned areas. Also, like in 2008, the vast majority of of these individuals flowered.

The importance of fire in savanna has been well established (Ramos-Neto \& Pivello 2000; Pivello 2006; Simon et al. 2009; Midgley et al. 2010). Prior studies of post-fire phenological response, with the exception of Stirlingia latifolia, an Australian species of Proteaceae (Bowen \& Pate 2004), did not report the exceptionally high degree of flowering that was observed for $V$. sincorana in the present study (e.g., Lamont \& Downes 1979; Givnish et al. 1986; Johnson et al. 1994; Curtis 1998; Taylor et al. 1998; Lamont et al. 2000; Franceschinelli \& Bawa 2005).

Anatomical studies to identify flowering and fire episodes on the older, longest branches of $V$. sincorana could make it possible to infer campos rupestres fire frequency by merging age information (as much as 100 years old in other Velloziaceae species) (Alves 1994), presence of charcoal, and flowering triggered by fire (Lamont \& Downes 1979; Müller 2006). The two most recent episodes of fire in the Morro dos Ventos population (1999 and 2008) are known and could be used to calibrate fire frequency estimates. This information, acquired for many sites, can help explain ecological processes in savannas in support of fire management and biodiversity conservation. Recent research on the genetic variations of populations of other Vellozia species in campos rupestres stressed the importance of genetic diversity of these species to habitat preservation (Franceschinelli et al. 2006), which is influenced by fire occurrence. Fire occurrence can have a general and sporadic influence on the dispersal and distribution of individuals in time and space, which in turn has a positive effect on diversity (Safford 2001). Illegal and uncontrolled fires, however, can increase fire frequency, leading to mortality in a system otherwise well-adapted to fire, particularly when these unnatural fires occur during an unfavorable season for the vegetation (Whelan 1995; Curtis 1998; Lamont et al. 2000; Ramos-Neto \& Pivello 2000; Franceschinelli \& Bawa 2005; Pivello 2006). Understanding the relationship between fire and phenology of a species is important for campos rupestres' ecosystem function, as well as the lives of local people can provide insights important to fire ecology that can support both conservation and more sustainable use.

\section{Acknowledgements}

The authors would like to thank FAPESB for the financial Project (TO 113/2007), as well as ICMBio for the concession of the license to work in National Park and additional sup-
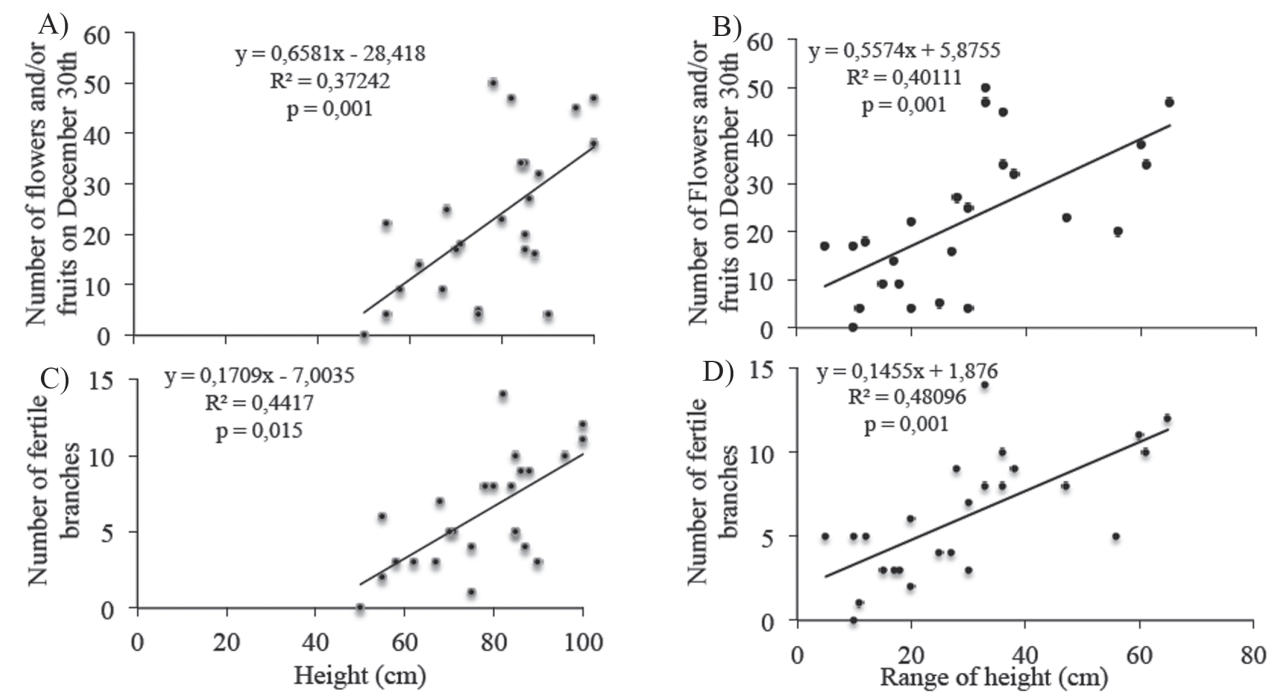

Figure 5. Linear regression between plant height and two factors: the total number of flowers and fruits (a, c), and the total of branches with flowers and fruits (b, d) of 25 individuals of Vellozia sincorana in Morro dos Ventos, Chapada Diamantina National Park, Bahia, Brazil. 
port from CAPES/DGU for scholarship (BEX 0963/10-0). We also thank Julio Roberto Gutierrez Camus and the two anonymous referees for their helpful review and comments.

\section{References}

Alves, R.J.V. 1994. Morphological age determination and longevity in some Vellozia populations in Brazil. Folia Geobotanica et Phytotaxonomica 29: 55-59.

Bowen, B.J. \& Pate J.S. 2004. Effect of season on shot recovery and postfire flowering performance in the resprouter Stirlingia latifolia R.Br. (Proteaceae). Austral Ecology 29: 145-155.

Cochrane, M.A. 2009. Tropical fire ecology: climate change, land use, and ecosystem dynamics. Chichester, Springer-Praxis.

Conceição A.A. \& Pirani J.R. 2005. Delimitação de habitats em campos rupestres na Chapada Diamantina: substratos, composição florística e aspectos estruturais. Boletim de Botânica da Universidade de São Paulo 23: 85-111.

Conceição, A.A.; Funch L.S. \& Pirani J.R. 2007a. Reproductive phenology, pollination and seed dispersal syndromes on sandstone outcrop vegetation in the "Chapada Diamantina", northeastern Brazil: population and community analyses. Revista Brasileira de Botânica 30: 475-485.

Conceição, A.A.; Giulietti, A.M. \& Meirelles, S.T. 2007b. Ilhas de vegetação em afloramentos de quartzito-arenito no Morro do Pai Inácio, Chapada Diamantina, Bahia, Brasil. Acta Botanica Brasilica 21: 335-347.

Coutinho L.M. 1977. Aspectos ecológicos do fogo no cerrado. IIAs queimadas e a dispersão de sementes em algumas espécies anemocóricas do estrato herbáceo-subarbustivo. Boletim de Botânica da Universidade de São Paulo 5: 57-64.

Curtis P.N. 1998. A post-fire ecological study of Xanthorrhoea australis following prescribed burning in the Warby Range State Park, Northeastern Victoria, Australia. Australian Journal of Botany 46: 253-272.

Franceschinelli E.V. \& Bawa K.S. 2005. The post-fire effects on the outcrossing rate of Brazilian savannah shrub, Helicteres sacarolha A.St.-Hil. Revista Brasileira de Botânica 28: 163-170.

Franceschinelli, E.V.; Jacobi, C.M.; Drummond, M.G. \& Resende, M.F.S. 2006. The genetic diversity of two Brazilian Vellozia (Velloziaceae) with different patterns of spatial distribution and pollination biology. Annals of Botany 97: 585-592.

Funch, L.S.; Harley, R.M.; Funch, R.; Giulietti, A.M. \& Melo, E. 2004. Plantas úteis da Chapada Diamantina. São Carlos, Rima.

Garcia, S.G. \& Diniz, I.S.S. 2003. Comportamento germinativo de três espécies de Vellozia da Serra do Cipó, MG. Acta Botanica Brasilica 17: 487-494.

Givnish, T.J.; McDiarmid, R.W. \& Buck, W.R. 1986. Fire adaptation in Neblinaria (Theaceae), a high-elevation rosette shrub endemic to a wet equatorial tepui. Oecologia 70: 481-485.

Jacobi, C.M. \& Sarto, M.C.L. 2007. Pollination of two species of Vellozia (Velloziaceae) from high-altitude quatzitic grasslands, Brazil. Acta Botanica Brasilica 21: 325-333.

Johnson, K.A.; Morrison, D.A. \& Goldsack, G. 1994. Postfire flowering patterns in Blandfordia nobilis (Liliaceae). Australian Journal of Botany 42: 49-60.

Kolbek, J. \& Alves, R.J.V. 2008. Impacts of cattle, fire and wind in Rocky Savannas, Southeastern Brazil. Acta Universitatis Carolinae Environmentalica 22: 111-130.

Kubitzki, K. 1998. Velloziaceae. Pp. 459-467. In: Kubitzki, K. (Ed.). The families and genera of vascular plants. Flowering plants, Monocotyledons, Lilianae (except Orchidaceae). v. 1. Berlin, Springer Verlag.

Lamont, B.B. \& Downes, S. 1979. The longevity, flowering and fire history of the grasstrees Xanthorrhoea preissii and Kingia australis. Journal of Applied Ecology 16: 893-899.

Lamont, B.B.; Swanborough, P.W. \& Ward, D. 2000. Plant size and season of burn affect flowering and fruiting of the grasstree Xanthorrhoea preissii. Austral Ecology 25: 268-272.
Mello-Silva, R. 2004. Novitates Velloziacearum florae phanerogamicae Sancti Pauli. Revista Brasileira de Botânica 27: 453-462.

Mello-Silva, R. 2010. Velloziaceae. In: Lista de Espécies da Flora do Brasil. Rio de Janeiro, Jardim Botânico do Rio de Janeiro. Disponível em: http://floradobrasil.jbrj.gov.br/2010/FB000245. (Acesso em 10/01/2011).

Midgley, J.J.; Lawes, M.J. \& Chamaillé-Jammes, S. 2010. Savanna woody plant dynamics: the role of fire and herbivory, separately and synergistically. Australian Journal of Botany 58: 1-11.

Montserrat, V. 1997. Effects of root competition and shading on resprouting dynamics of Erica multiflora L. Journal of Vegetation Science 8: 71-80.

Moreira, A.A.N. \& Camelier, C. 1977. Geografia do Brasil: Região Nordeste. Vol. 2. Rio de Janeiro, Fundação Instituto Brasileiro de Geografia e Estatística.

Müller, G. 2006. A new frequency analysis method for constructing fire histories from flowering events in Austral grasstrees (Xanthorrhoea australis) from Southern Victoria. Geographical Research 44: 339-347.

Munné-Bosch, S.; Oñate, M.; Oliveira, P.G. \& Garcia, Q.S. 2011. Changes in phytohormones and oxidative stress markers in buried seeds of Vellozia alata. Flora 206: 704-711.

McNeely, J.A.; Miller, K.R.; Reid, W.V.; Mittermeier, R.A. \& Werner, T.B. 1990. Conserving the world's biological diversity. Gland, IUCN.

Neves, S.P.S. \& Conceição, A.A. 2010. Campo rupestre recém-queimado na Chapada Diamantina, Bahia, Brasil: plantas de rebrota e sementes, com espécies endêmicas na rocha. Acta Botanica Brasilica 24: 697-707.

Nimer, N. 1989. Climatologia do Brasil. Rio de Janeiro, Fundação Instituto Brasileiro de Geografia e Estatística.

Paula, S. \& Pausas, J.G. 2008. Burning seeds: germinative response to heat treatments in relation to resprouting ability. Journal of Ecology 96: 543-552.

Pyke, G.H. 1983. Relationship between time since the last fire and flowering in Telopea speciosissima R.Br. and Lambertia formosa Sm. Australian Journal of Botany 31: 293-296.

Pivello, V.R. 2006. Fire management for biological conservation in the Brazilian cerradão. Pp. 129-154. In: Mistry, J. \& Berardi, A. (Eds.). Savannas and Dry Forests - Linking People with Nature, Vol. 1. Ashgate, Hants.

Porembski, S. \& Barthlott, W. 1995. On the occurrence of a velamen radicum in Cyperaceae and Velloziaceae. Nordic Journal of Botany 15: 625-629.

Ramos-Neto, M.B. \& Pivello, V.R. 2000. Lightning fires in a Brazilian savanna national park: rethinking management strategies. Environmental Management 26: 675-684.

Ramsay, P.M. \& Oxley, R.B. 1996. Fire temperatures and postfire community dynamics in Ecuadorian grass páramo. Vegetatio 124: 129-144.

Safford, H.D. 2001. Brazilian páramos. III. Patterns and rates of postfire regeneration in the campos de altitude. Biotropica 33: 282-302.

Schmidt, I.B.; Sampaio, A.B. \& Borghetti, F. 2005. Efeitos da época da queima sobre a reprodução sexuada e estrutura populacional de Heteropterys pteropetala (Adr. Juss.), Malpighiaceae, em áreas de Cerrado sensu stricto submetido a queimas bienais. Acta Botanica Brasilica 19: 927-934.

Simon, M.F.; Grether, R.; Queiroz, L.P.; Skema, C.; Pennington, R.T. \& Hughes, E. 2009. Recent assembly of the cerrado, a neotropical plant diversity hotspot, by in situ evolution of adaptations to fire. Proccedings of the National Academy of Sciences of United States of America 106: 20359-20364.

Smith, L.B. \& Ayensu, S. 1976. A revision of American Velloziaceae. Smithsonian Contributions to Botany 30: 1-172.

Taylor, J.E.; Monamy, V. \& Fox, B.J. 1998. Flowering of Xanthorrhoea fulva: the effect of fire and clipping. Australian Journal of Botany 46: 241-251.

Verboom, G.A.; Stock, W.D. \& Linder, H.P. 2002. Determinants of postfire flowering in the geophytic grass Ehrharta capensis. Functional Ecology 16: 705-713.

Whelan, R.J. 1995. The ecology of fire. Cambridge, Cambridge University Press. 